\title{
BACE-1 inhibition prevents the $\gamma$-secretase inhibitor evoked $A \beta$ rise in human neuroblastoma SH-SY5Y cells
}

\author{
Anne Jämsä, Oscar Belda, Michael Edlund and Erik Lindström*
}

\begin{abstract}
Background: Accumulation of amyloid $\beta$-peptide $(A \beta)$ in the plaques is one of the major pathological features in Alzheimer's disease (AD). Sequential cleavage of amyloid precursor protein (APP) by $\beta$-site APP cleaving enzyme 1 (BACE-1) and $\gamma$-secretase results in the formation of $A \beta$ peptides. Preventing $A \beta$ formation is believed to attenuate $A D$ progression and BACE-1 and $\gamma$-secretase are thus attractive targets for AD drug development.

Methods: Combining BACE-1 and $\gamma$-secretase inhibition on A $\beta$ secretion from human neuroblastoma SH-SY5Y cells was evaluated in this study. Secreted A 40 and A 42 levels were measured from SH-SY5Y cells stably transfected with APPwt or APPswe genes. A selective BACE inhibitor and the $\gamma$-secretase inhibitor LY450139 (semagacestat) were used to inhibit respective secretase.

Results: LY450139 increased A 40 and Aß42 secretion from SH-SY5Y APPwt cells at low concentrations (by 60\% at $3 \mathrm{nM})$ followed by subsequent inhibition at higher concentrations $\left(\mathrm{IC}_{50} 90 \mathrm{nM}\right)$. Washout studies showed that the A $\beta$ increase evoked by 3 nM LY450139 was not due to enhanced cleavage following substrate accumulation but rather to activation of A $\beta$ formation. By contrast, LY450139 inhibited A $\beta$ formation from SH-SY5Y APPswe in a monophasic manner $\left(\mathrm{IC}_{50} 18 \mathrm{nM}\right)$. The BACE inhibitor per se inhibited A $\beta$ secretion from both SH-SY5Y APPwt and SH-SY5Y APPswe cells with $I C_{50}$ S ranging between $7-18 \mathrm{nM}$ and also prevented the increased $A \beta$ secretion evoked by 3 nM LY450139. Combining the BACE inhibitor with higher inhibitory concentrations of LY450139 failed to demonstrate any clear additive or synergistic effects.
\end{abstract}

Conclusion: BACE-1 inhibition attenuates the A $\beta$ increase evoked by LY450139 while not providing any obvious synergistic effects on LY450139-mediated inhibition.

\section{Background}

Alzheimer's disease (AD) is the most common form of dementia in human with amyloid plaques and neurofibrillary tangles being hallmark features. The enzymatic cascade involved in the formation of $A \beta 1-40$ and $A \beta 1$ 42 peptides, the predominant species of plaques, has been characterized in detail (for a recent review see [1]). Amyloid precursor protein (APP) is cleaved by $\beta$-site APP cleaving enzyme-1 (BACE-1) followed by subsequent cleavage by the $\gamma$-secretase complex to form $A \beta$ peptides. It is still not clear what the assumed neurotoxic agent is, although recent data suggest $A \beta$ dimers

\footnotetext{
* Correspondence: Erik.Lindstrom@medivir.se

Medivir AB, Lunastigen 7, PO Box 1086, S-14122 Huddinge, Sweden
}

and oligomers as being the most neurotoxic $A \beta$ assemblies [2].

Nonetheless, it is widely believed that inhibiting the formation of $\mathrm{A} \beta$, either by inhibiting BACE- 1 or $\gamma$-secretase would be of benefit for AD patients, regardless which $A \beta$ assembly is the neurotoxic agent. Quite some progress has been made with respect to $\gamma$-secretase inhibition. The furthest advanced compound LY450139 (semagacestat) was shown to lower $A \beta$ levels in the cerebrospinal fluid from healthy volunteers [3]. Other $\gamma$ secretase inhibitors have achieved similar results clinically. Hence, central efficacy appears clinically feasible with this class of drugs. However, safety issues have been raised by inhibiting this drug target since $\gamma$-secretase also cleaves Notch protein, a substrate that plays an important role in cellular differentiation. Indeed, $\gamma$ -

\section{() Biomed Central}

(c) 2011 Jämsä et al; licensee BioMed Central Ltd. This is an Open Access article distributed under the terms of the Creative Commons Attribution License (http://creativecommons.org/licenses/by/2.0), which permits unrestricted use, distribution, and reproduction in any medium, provided the original work is properly cited. 
secretase inhibitors have produced hyperplasia of intestinal Goblet cells and altered tissue morphology in rodents $[4,5]$. Also, inhibitors cause thymus atrophy preclinically [5] and reduce circulating $B$ cells in patients [6]. Two subsequent $\gamma$-secretase inhibitors, begacestat [7] and BMS708163 [8], with improved selectivity towards Notch have reached clinical development. Nonetheless, Notch liabilities may limit the doses that can be given safely.

Inhibition of $\gamma$-secretase leads to $A \beta$ reductions in plasma and in brain if desired compound levels are reached. Interestingly, after lowering A $\beta$ levels at efficacious doses, $A \beta$ subsequently rise to levels substantially higher than baseline levels, often referred to as a rebound effect. However, low, sub-efficacious doses of $\gamma$ secretase inhibitor also appear to increase $A \beta$ levels putting the mechanism behind the rebound phenomena into question and instead suggesting an $A \beta$ rise at low concentrations without previous inhibition. This $A \beta$ rise phenomena has mainly been demonstrated in plasma in mice, guinea pigs, beagle dogs and healthy human volunteers [9-11] but also in cerebrospinal fluid in guinea pigs [10] and in rat brains [12]. The $A \beta$ rebound/ rise phenomena seems to be a target class-related effect, since similar findings have been demonstrated with chemically distinct $\gamma$-secretase inhibitors [7]. However, a recently characterized $\gamma$-secretase inhibitor, PF-3084014 appears to lack this attribute preclinically [13]. The possible impact of $\mathrm{A} \beta$ rebound/rise on $\mathrm{AD}$ disease progression is unknown; however it is not inconceivable that non-compliant patients could be exposed to sub-efficacious levels of $\gamma$-secretase inhibitor resulting in elevated concentrations of A $\beta$. Recently, a phase III clinical trial with LY450139 (semagacestat) in AD patients was discontinued prematurely [14]. Surprisingly it was reported that patients receiving LY450139 fared worse than placebo-treated controls with respect to cognitive symptoms.

Less progress has been made with respect to BACE-1 inhibition. Although BACE inhibitors reduce $\mathrm{A} \beta$ levels in brain or cerebrospinal fluid in PgP KO mice [15], APP transgenic mice [16-18], wild type mice [19] and rhesus monkey [20], there is limited data demonstrating central $A \beta$-lowering effects in man. The lack of progress of clinical BACE inhibitors is due to the difficulty of combining adequate potency with good $\mathrm{PK}$ properties (e.g. permeability over the BBB, efflux, protein binding, metabolism).

Considering that 1) $\gamma$-secretase inhibitors have possible safety issues which may reduce the doses regarded as safe and 2) most $\gamma$-secretase inhibitors appear to cause increases of $A \beta$ levels at low concentrations and 3) central efficacy with BACE inhibitors is difficult to achieve, the aim of the present study was to evaluate if BACE-1 inhibition could prevent the $A \beta$ rebound/rise evoked by a $\gamma$-secretase inhibitor and if synergistic efficacy on $A \beta$ secretion could be achieved by combining BACE and $\gamma$ secretase inhibitors.

\section{Materials and methods Inhibitors}

The $\gamma$-secretase inhibitor $(\mathrm{N})-((S)$-2-hydroxy-3-methylbutyryl)-1-(L-alaninyl)-(S)-amino-3-methyl-2,3,4,5-tetrahydro-1H-3-benzazepin-2-one dihydrate (LY450139, semagacestat) was made in-house as described in Audia et al. [21]. The BACE-inhibitor N-[(1S,2R)-1-Benzyl-3(cyclopropylamino)-2-hydroxypropyl]-7-ethyl-1-methyl3,4-dihydro-1H-[1,2,5] thiadiazepino[3,4,5-hi-]indole-9carboxamide 2,2-Dioxide (compound 8e in Charrier et al., 2008) was made in-house as described in Charrier, et al. [22]. The compound is referred to as "BACE inhibitor" throughout the present paper. The molecular structures of the BACE inhibitor and LY450139 are shown in Figure 1.

\section{Cell culture}

The human neuroblastoma cell line SH-SY5Y was purchased from European Collection of Cell Cultures (ECACC). Cells were grown in DMEM/Ham's F-12

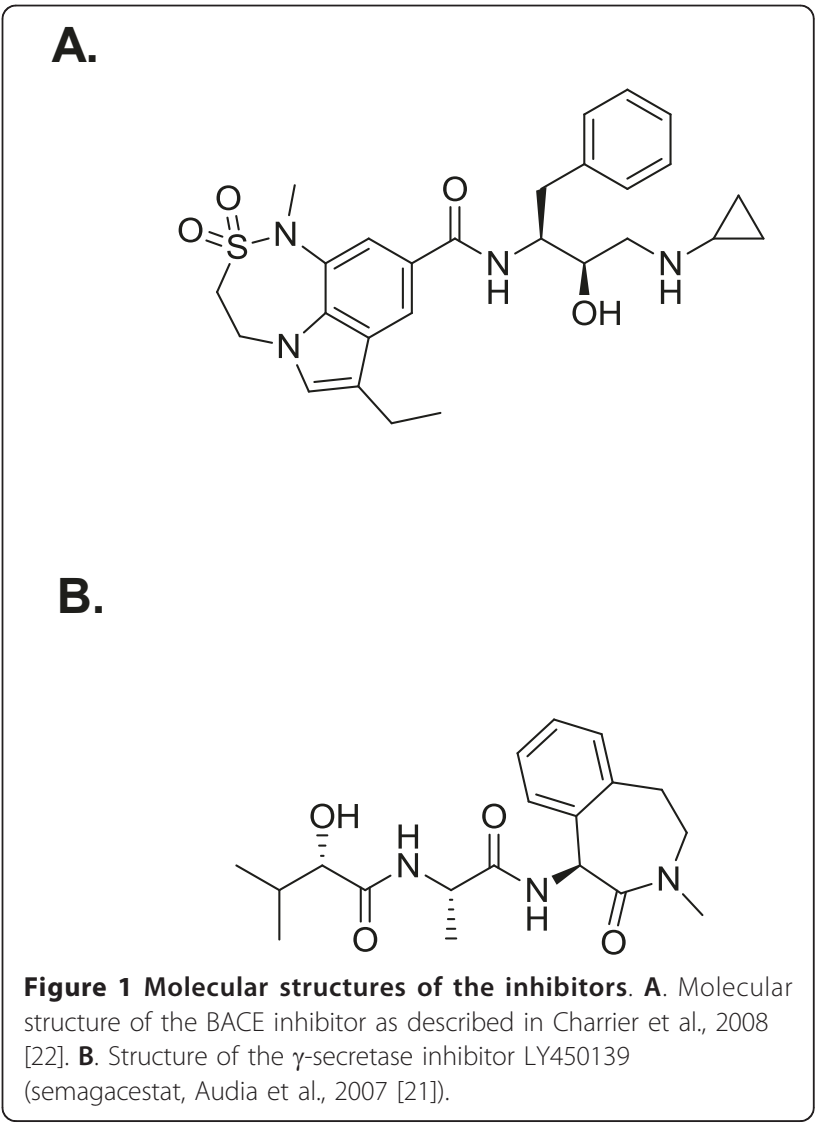


(PAA), supplemented with $1 \%$ non-essential amino acids (PAA) and 10\% Fetal Bovine Serum (PAA). Cells were maintained at $37^{\circ} \mathrm{C}$ in a humidified atmosphere containing $5 \% \mathrm{CO}_{2}$.

SH-SY5Y cells were stably transfected with plasmids carrying human APPwt or APPswe gene. APP gene was purchased from Geneservice Ltd (clone sequence BC065529; clone MGC75167) and the APPswe mutation was generated using a QuikChange ${ }^{\circledR}$ Site-Directed Mutagenesis Kit (Stratagene). APPwt and APPswe genes were cloned into a mammalian expression vector pcDNA3.1 and the expression was under the control of CMV promotor. The cells were plated at the density of $6.25 \times 10^{4}$ cells $/ \mathrm{cm}^{2}$ in 6 -well culture dishes (Sarstedt) and each well was transfected with $4 \mu \mathrm{g}$ plasmid DNA. Lipofectamine ${ }^{\mathrm{TM}} 2000$ (InVitrogen) was used as a transfection reagent according to manufacturer's instructions. The transfected cells were selected with $400 \mu \mathrm{g} / \mathrm{ml}$ G418 (PAA).

Cells were plated at a density of $6.25 \times 10^{4} \mathrm{cells} / \mathrm{cm}^{2}$ in 96-well cell culture plates (TRP) for A $\beta$ measurements with ELISA or in 6-well culture dishes (Sarstedt) for Western blot. The day after the plating of the cells, the cultures were treated with various concentrations of $\gamma$-secretase inhibitor LY450139 or the BACE inhibitor for 24 hours. Stock solutions of inhibitors were prepared in dimethyl-sulfoxide (DMSO). All cultures including the control cells received equal amounts of DMSO, the final concentration being $0.1 \%$. All the results were from two to three separate experiments and the data presented as means \pm SEM.

\section{ELISA}

The secreted $A \beta 40$ and $A \beta 42$ peptides in cell culture media were measured using human amyloid $\beta 40$ or $\beta 42$ ELISA kits from Millipore. The absorbance was measured at $450 \mathrm{~nm}$ by Microplate reader (Molecular Devices). Data from inhibitor-treated cell cultures was expressed as a percent of untreated controls and the inhibition curves were analysed by non-linear regression using Graph Pad Prism.

\section{Western blot}

SH-SY5Y cells were lysed in buffer containing $50 \mathrm{mM}$ Tris- $\mathrm{HCl} \mathrm{pH}$ 8.0, $150 \mathrm{mM} \mathrm{NaCl}$ 1\% Triton X-100, $1 \mathrm{mM}$ EDTA, $1 \mathrm{mM} \mathrm{Na}_{3} \mathrm{VO}_{4}$ and 1 complete protease inhibitor cocktail tablet (Roche Diagnostics)/10 ml buffer. The cells were incubated with lysis buffer for 10 minutes on ice before scraping the cells from the dishes. Cell lysates were centrifuged at $14000 \mathrm{rpm}$ for 15 minutes. The protein content in the supernatants was measured using Pierce ${ }^{\circledR}$ $660 \mathrm{~nm}$ Protein Assay kit. Samples, containing $20 \mu \mathrm{g}$ protein, were resolved in $7 \%$ NuPAGE ${ }^{\circledR}$ Tris-Acetate gels (InVitrogen) using Tris-Acetate SDS running buffer
(InVitrogen). The proteins were transferred to PVDF membranes using iBlot ${ }^{\mathrm{TM}}$ gel transfer stacks (InVitrogen). Membranes were blocked in PBS with $0.05 \%$ Tween 20 containing 3\% non-fat dry milk for 1 hour at RT. Mouse $\beta$ amyloid (6E10) monoclonal antibody (Signet laboratories) was diluted 1:1000 and the $\beta$-actin antibody (SigmaAldrich) 1:10 000 in 1\% milk and incubation was carried out at $4{ }^{\circ} \mathrm{C}$ over night. Horseradish-peroxidase (HRP) conjugated anti-mouse secondary antibody (Amersham Biosciences) was incubated 1 hour at RT in $1 \%$ milk at the dilution of 1:3000. Blots were developed using the Super Signal $^{\circledR}$ detection system (Pierce). Average density of the bands was measured in ChemiDoc ${ }^{\mathrm{TM}}$ XRS (Bio-Rad) by using Quantity One software.

\section{Results}

\section{APP expression and $A \beta$ secretion from APPwt- and} APPswe-transfected SH-SY5Y cells

Transfection of APPwt and especially APPswe genes into SH-SY5Y cells increased APP expression compared to non-transfected cells (Figure 2A). The 6E10 antibody that binds to amino acid residues $1-16$ of $A \beta$ recognized three bands that are most likely isoforms of full-length APP or mature/immature APP differentially modified by glycosylation. Densitometric quantification of Western blot is shown in Figure 2B. The increase in APP level is approximately 50\% in APPwt transfected SH-SY5Y cells and $100 \%$ in APPswe transfected cells.

Baseline secretion of $A \beta 40$ and $A \beta 42$ during $24 \mathrm{~h}$ from non-transfected SH-SY5Y cells was only slightly above the level of detection while being readily measurable in cells transfected with APPwt (Figure 2C). By contrast, secreted $A \beta 40$ and $A \beta 42$ levels were approximately 15-fold higher from APPswe-transfected cells compared to APPwt-transfected (Figure 2C). APPswe gene has a double mutation at codons 670 and 671 located just $\mathrm{N}$-terminal of the $\mathrm{A} \beta \mathrm{N}$-terminus, which makes APP a better substrate for BACE resulting in increased production of total $A \beta[23]$.

\section{Effect of the $\gamma$-secretase inhibitor LY450139 on A 340 and A 342 secretion from SH-SY5Y APPwt and APPswe cells}

In SH-SY5Y APPwt cells, the $\gamma$-secretase inhibitor LY450139 produced a biphasic response with $A \beta 40$ levels increasing in response to low concentrations of inhibitor, reaching $60 \%$ above baseline at $3 \mathrm{nM}$ (Figure $3 \mathrm{~A})$. At higher concentrations (> $30 \mathrm{nM}$ ), A $\beta 40$ levels decreased with an approximate $\mathrm{IC}_{50}$ of $90 \mathrm{nM}$. By contrast, in SH-SY5Y APPswe cells, LY450139 produced a concentration-dependent inhibition of $A \beta 40$-secretion with a monophasic profile and an $\mathrm{IC}_{50}$ of $18 \mathrm{nM}$ (Figure 3A). Hence, under our experimental conditions, LY450139 was $\sim 5$-fold less potent at inhibiting A $\beta 40$ secretion from APPwt cells compared to APPswe cells. 
A.

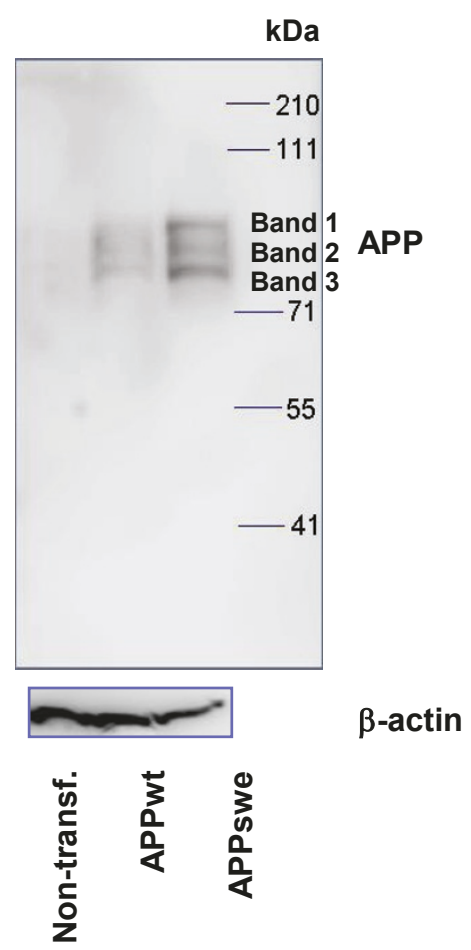

B.

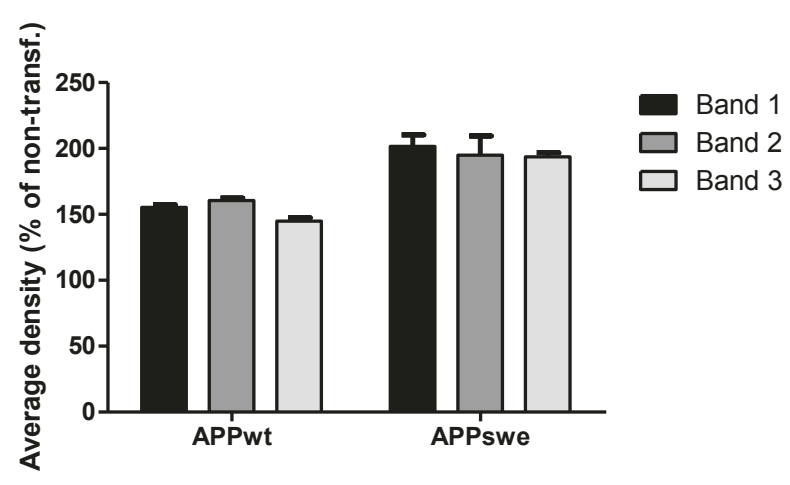

C.

\begin{tabular}{lll} 
& $\begin{array}{l}\mathbf{A} \beta 40 \\
(\mathrm{pg} / \mathrm{ml})\end{array}$ & $\begin{array}{l}\mathbf{A} \beta 42 \\
(\mathrm{pg} / \mathrm{ml})\end{array}$ \\
\cline { 2 - 3 } Non-transf. & $16 \pm 0.1$ & $10 \pm 0.9$ \\
APPwt & $200 \pm 35$ & $65 \pm 15$ \\
APPswe & $3300 \pm 760$ & $910 \pm 45$
\end{tabular}

Figure 2 APP expression and A 3 secretion in SH-SY5Y cells. A. APP expression in non-transfected, APPwt- and APPswe-transfected SH-SY5Y cells. The three bands detected with 6E10 antibody in the cell lysates are most likely isoforms of full-length APP or mature/immature APP differentially modified by glycosylation. B. Densitometric quantification shows 50\% increase of APP levels in APPwt transfected SH-SY5Y cells and $100 \%$ increase in APPswe transfected cells as compared to non-transfected ones. Data presented as means \pm SEM, $n=2$. C. A 340 and AB42 secretion during $24 \mathrm{~h}$ in non-transfected, APPwt- and APPswe-transfected SH-SY5Y cells.

At $3 \mathrm{nM}$, LY450139 also increased secreted A 342 levels by $70 \%$ in SH-SY5Y APPwt cells compared to controls, while secreted $A \beta 42$ levels from APPswe cells were not affected (Figure $3 \mathrm{~B})$.

\section{Washout experiments with LY450139 in SH-SY5Y APPwt and APPswe cells}

The previously mentioned experiments were performed under closed-conditions, i.e. LY450139 was present during the whole incubation period $(24 \mathrm{~h})$ at a presumed constant concentration. In order to detect a possible $A \beta$ rebound, we performed washout experiments. Incubating SH-SY5Y APPwt cells with $300 \mathrm{nM}$ LY450139 for 24 h reduced $A \beta 40$ secretion by $80 \%$ compared to control (Figure 4A), consistent with previous results (see Figure 3A). After 24 h, The LY450139-containing media and control media were washed out and replaced with fresh media without inhibitor and $A \beta 40$ secretion was followed for an additional $24 \mathrm{~h}$. In control cells, $A \beta 40$ secretion during the subsequent $24 \mathrm{~h}$ did not differ from $A \beta 40$ secretion during the initial $24 \mathrm{~h}$ indicating that washout per se does not affect SH-SY5Y secretory function (Figure 4A). A $\beta 40$ secretion during $24 \mathrm{~h}$ from SH-SY5Y APPwt cells that had been pre-treated with
300 nM LY450139-containing media did not differ from control cells.

In analogy to $\mathrm{A} \beta 40, \mathrm{~A} \beta 42$ secretion from $\mathrm{SH}-\mathrm{SY} 5 \mathrm{Y}$ APPwt cells returned to control levels after inhibition with $300 \mathrm{nM}$ LY450139 for $24 \mathrm{~h}$ without any evidence of a rebound (Figure 4B).

Treatment with 3, 30 or 300 nM LY450139 for $24 \mathrm{~h}$ resulted in accumulation of substrate as shown in Figure $4 \mathrm{C}$ with densitometric quantification of the bands summarized in Figure 4D. This suggests that the substrate accumulation seen during the initial 24 hours did not lead to excessive $A \beta 40$ secretion during the next $24 \mathrm{~h}$. Shorter time periods ( 2 - 6 hours) after washout were also monitored in order to detect any possible immediate and short-acting $A \beta 40$ rebound. However, $A \beta 40$ production did not differ between LY450139 pre-treated and control cells at these shorter time points (data not shown).

Since 3 nM LY450139 evoked an A $\beta$ rise from SHSY5Y APPwt cells under standard closed conditions (see Figure $3 \mathrm{~A}$ ), we wished to evaluate how this low concentration of inhibitor would act following inhibition of $A \beta$ production over $24 \mathrm{~h}$ with a high concentration (300 $\mathrm{nM}$ ) of LY450139 which leads to substrate 


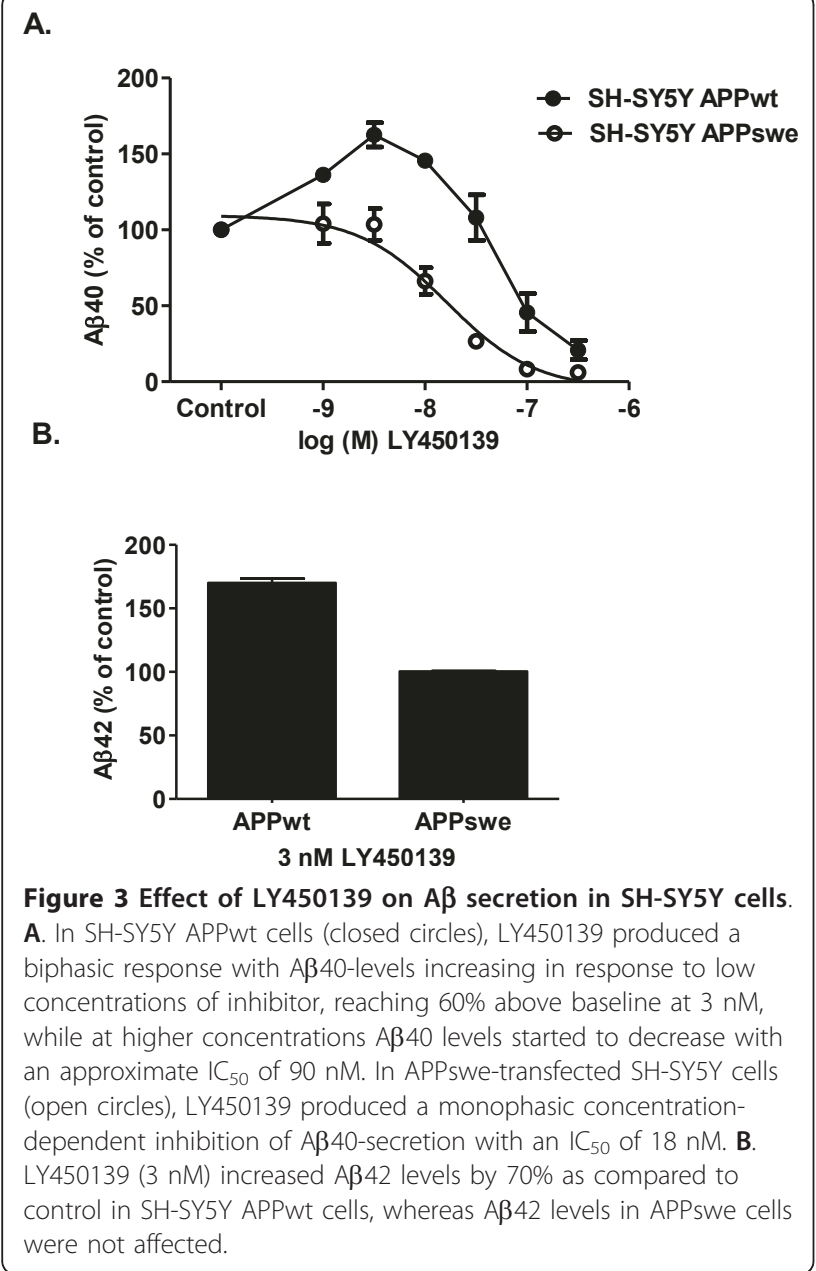

accumulation. Treatment with 300 nM LY450139 over 24 h inhibited $A \beta$ secretion by $80 \%$ as expected (Figure $5 A$ ). Replacing the medium with $3 \mathrm{nM}$ LY450139 during the second $24 \mathrm{~h}$ incubation period, increased $\mathrm{A} \beta 40$ levels by $60 \%$ compared to the cells that during the first $24 \mathrm{~h}$ period received $300 \mathrm{nM} \mathrm{LY450139}$ and during the second incubation period received fresh medium (Figure 5A). This phenomenon was not seen in SH-SY5Y APPswe cells, where treatment with $300 \mathrm{nM}$ LY450139 followed by $3 \mathrm{nM}$ LY450139 did not lead to increased A $\beta 40$ levels (Figure 5B). Hence, 3 nM LY450139 evokes a similar degree of A $\beta$ rise in SH-SY5Y APPwt cells, regardless if cells are pre-treated with a high concentration of inhibitor (leading to substrate accumulation) or not.

\section{Effect of concomitant BACE-1 inhibition on the $A \beta$ rise evoked by LY450139}

In SH-SY5Y APPwt cells, the BACE inhibitor inhibited $A \beta 40$-secretion in a concentration-dependent manner with an $\mathrm{IC}_{50}$ of $7 \mathrm{nM}$ and prevented the $\mathrm{A} \beta$ rise evoked by $3 \mathrm{nM}$ LY450139 with an $\mathrm{IC}_{50}$ of $23 \mathrm{nM}$ (Figure 6A).
The BACE inhibitor had a similar potency when constructing the concentration response curve in the presence of $30 \mathrm{nM}$ LY450139 (a concentration which per se does not affect basal A 340 levels) as without LY450139 (10 nM vs. $7 \mathrm{nM}$, Figure 6A). In Figure 6B the same results (from Figure (6A) are illustrated in an alternative manner. Here it is highlighted how the LY450139evoked $A \beta 40$ rise is still present but attenuated in the presence of $3 \mathrm{nM}$ BACE inhibitor. $30 \mathrm{nM}$ BACE inhibitor was required to abolish the LY450139-evoked A $\beta 40$ rise completely.

The same series of experiments were performed in SH-SY5Y APPswe cells. The BACE inhibitor reduced basal A $\beta 40$-secretion from SH-SY5Y APPswe cells in a concentration-dependent fashion with an $\mathrm{IC}_{50}$ of $18 \mathrm{nM}$ (Figure 7A). The potency of the BACE inhibitor was weaker $\left(\mathrm{IC}_{50} 110 \mathrm{nM}\right.$, Figure $\left.7 \mathrm{~A}\right)$ in the presence of 3 nM LY450139 (a concentration that does not affect $\mathrm{A} \beta 40$-secretion per se - see Figure 3A). The figure highlights that $3 \mathrm{nM}$ LY450139, although not producing an A 440 rise in APPswe transfected cells, appears to counteract the potency of the BACE inhibitor. In the presence of $30 \mathrm{nM}$ LY450139, the BACE inhibitor reduced remaining $A \beta 40$ secretion (20-30\% remaining) with an $\mathrm{IC}_{50}$ of $0.2 \mathrm{nM}$ (Figure 7A). Figure 7B illustrates the data in a different manner. The figure highlights that overall $\mathrm{A} \beta 40$ levels are reduced when adding increasing concentrations of BACE inhibitor, although it seems as if $3 \mathrm{nM}$ LY450139 under these conditions tends to increase $A \beta 40$ levels compared to control cells treated with $B A C E$ inhibitor alone, reminiscent of the $A \beta$ rise seen in APPwt cells.

\section{Discussion}

Attenuating $\mathrm{A} \beta$ production, for instance by inhibiting either of the respective proteases BACE- 1 or $\gamma$-secretase, is considered an attractive strategy for preventing disease progression in patients suffering from Alzheimer's Disease. However, both of these protease inhibition approaches have met several challenges over recent years. BACE-1 has been a difficult target from a chemical tractability point of view with few compounds entering clinical development, most likely due to the difficulties in achieving the combination of necessary enzyme inhibition with adequate brain exposure. Moreover, compounds that target $\gamma$-secretase have been associated with severe side effects since several other substrates with likely physiological relevance are cleaved by the $\gamma$-secretase complex. When compound exposure wanes, treatment with $\gamma$-secretase inhibitors actually results in increased $A \beta$ levels, a so called $A \beta$ rebound/ rise. Considering these facts we felt it important to investigate whether combining a BACE inhibitor with a $\gamma$-secretase inhibitor would result in synergistic efficacy 


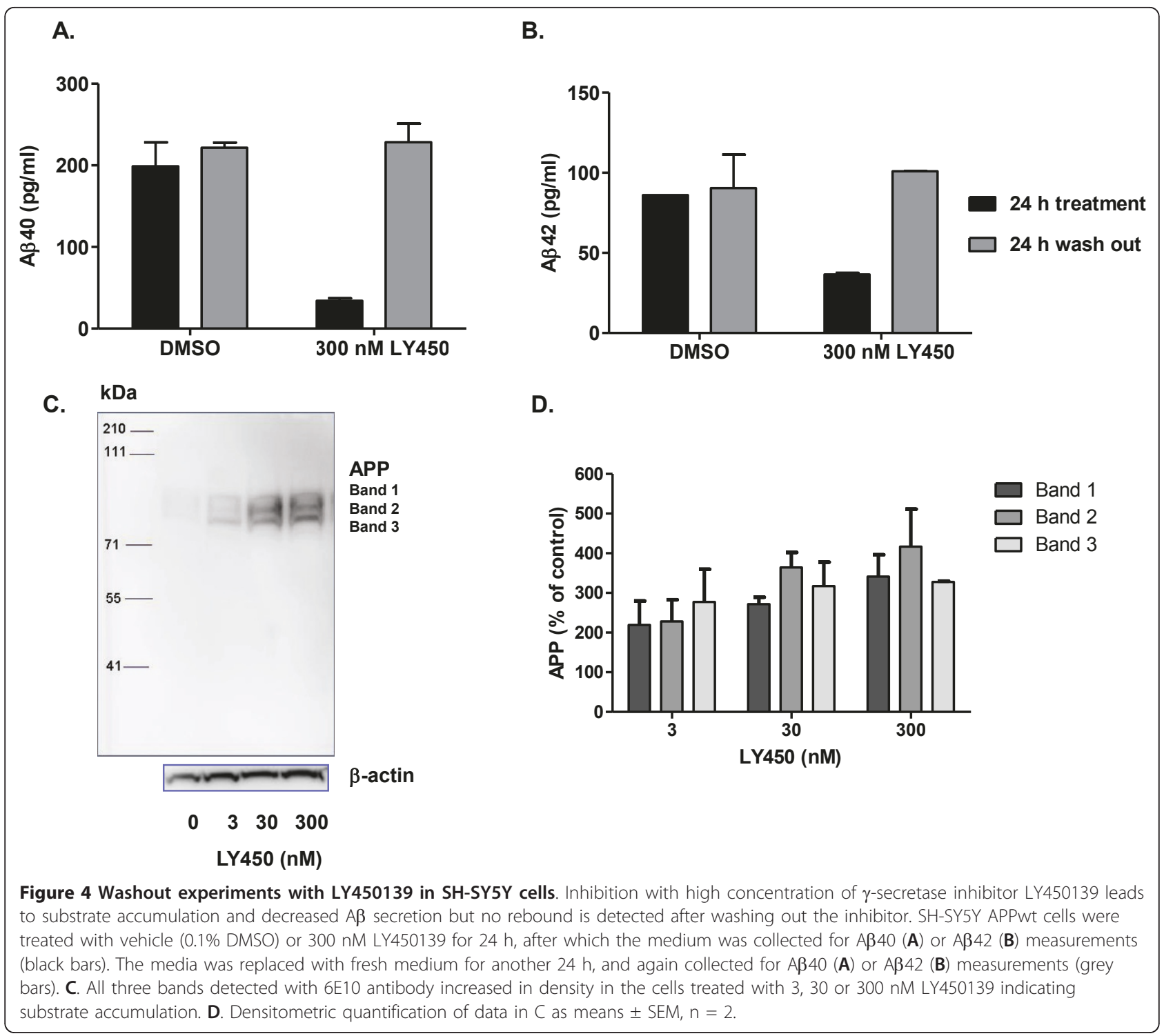

and whether a BACE inhibitor could prevent the $A \beta$ rebound/rise evoked by a $\gamma$-secretase inhibitor.

In our first set of experiments, we were able to verify that LY450139 increases both $A \beta 40$ and $A \beta 42$ levels at a low concentration in SH-SY5Y APPwt cells but not in SH-SY5Y APPswe cells. At higher concentrations, inhibition occurred with LY450139 being 5-fold less potent at inhibiting $A \beta$ secretion when using APPwt cells compared to APPswe cells. The potency of LY450139 using APPwt cells was similar to data reported from others [10] and the 5-fold shift in potency was very similar to Burton et al. [12], although they studied the $\gamma$-secretase inhibitor DAPT. This potency shift is presumably due to the differences in substrate/enzyme ratios.

The $A \beta$ rise/rebound has been claimed to involve substrate accumulation due to inhibition of the $\gamma$-secretase complex. The rationale being that after inhibition has subsided the accumulated substrate, BACE-1 cleaved fragment $C 99$, can more readily be converted to $A \beta$ resulting in the $A \beta$ rebound. However, sub-inhibitory doses of $\gamma$-secretase inhibitor also appear to increase $A \beta$ levels suggesting instead that an $A \beta$ rise occurs at low concentrations without previous inhibition [12]. Since the aim of this paper was to examine the effect of combining a $\gamma$-secretase inhibitor with a BACE inhibitor, we felt it important to first further elucidate whether a rebound-like effect or an $A \beta$ rise was occurring in response to $\gamma$-secretase inhibition before addressing the combination of inhibitors.

If an $A \beta$ rebound mechanism was behind the increased $A \beta$ levels seen in our studies in vitro, then one would expect to see increased $A \beta$ levels in the cell 


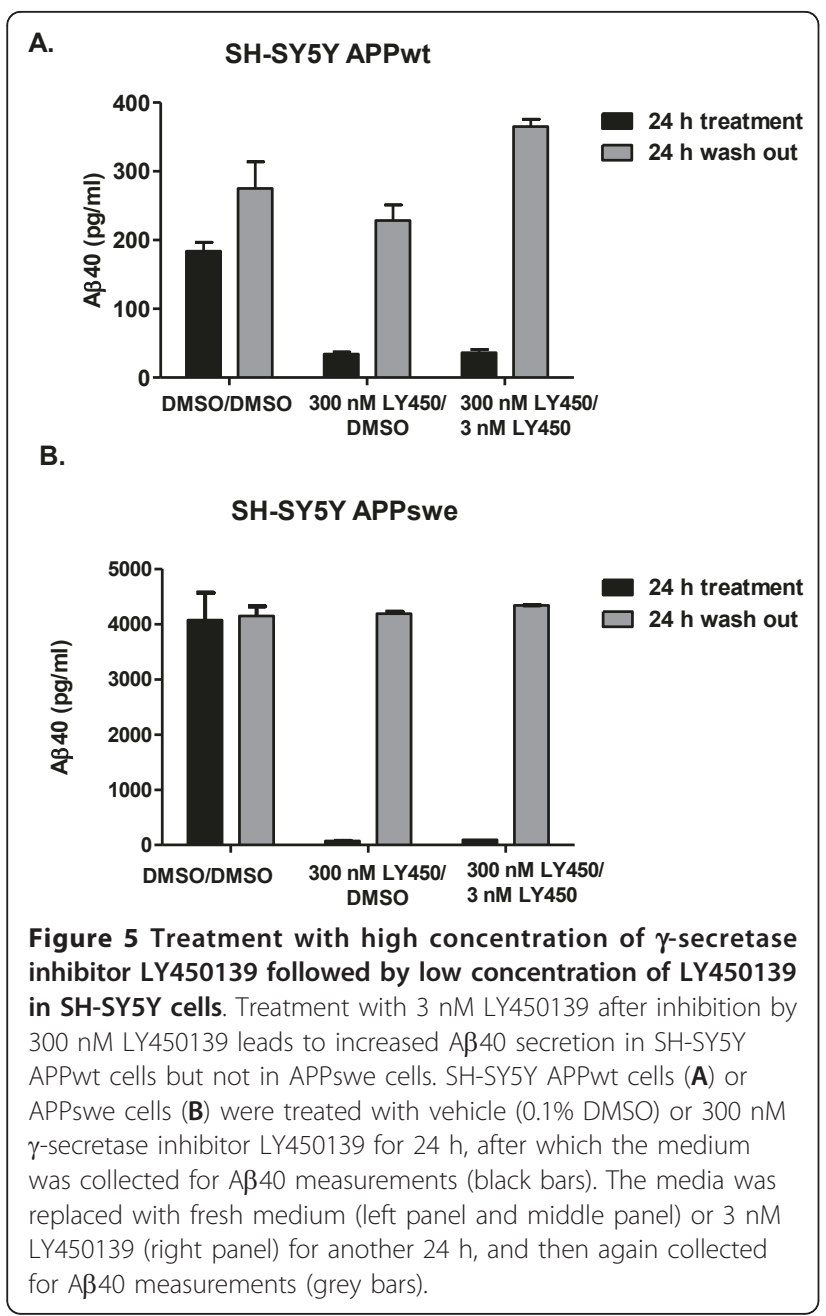

medium after first exposing cells to a high concentration of compound leading to $\gamma$-secretase inhibiton followed by washout. We tested this hypothesis in SH-SY5Y APPwt cells. Despite obvious substrate accumulation and decreased $A \beta$ secretion in response to $\gamma$-secretase inhibition, subsequent over-production of $A \beta$ was not detected when the inhibitor was washed out. We checked even shorter time points in case over-production would have occurred in a transient manner but this was not the case.

Burton et al. [12] suggested that the $A \beta$ rise would only occur under conditions where $\gamma$-secretase substrate levels are relatively low (i.e. SH-SY5Y APPwt cells). We tested this hypothesis by first giving an inhibitory concentration of LY450139 (300 nM) which resulted in substrate accumulation and thus higher substrate levels in APPwt cells and then replaced the medium with a low concentration of LY450139 (3 nM) which normally gives an $A \beta$ rise in low-substrate conditions. However, despite the increased substrate levels, 3 nM LY450139 resulted in a similar $A \beta$ rise as under control conditions without

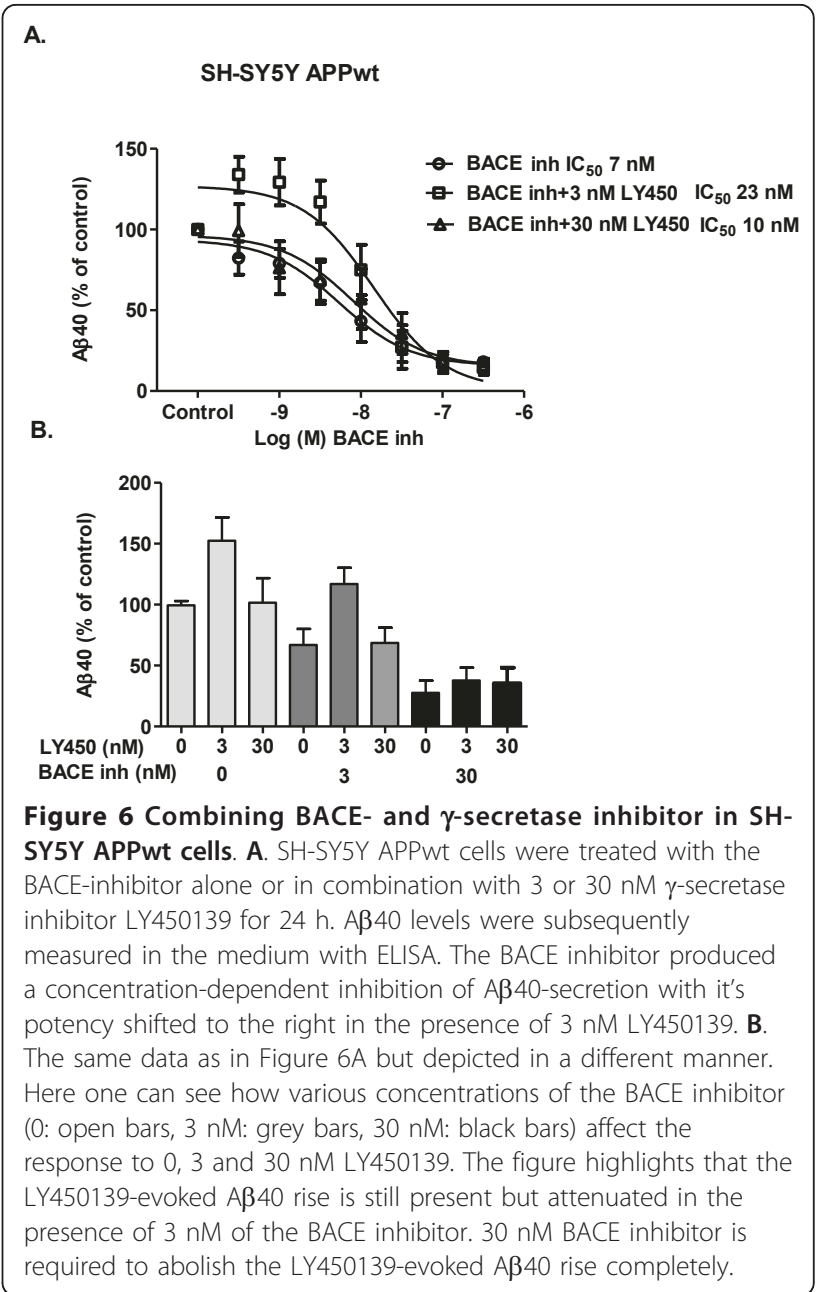

substrate accumulation. This could perhaps be due to the level of substrate not reaching levels present in for instance APPswe cells. Indeed, we were not able to detect an $A \beta$ rise in APPswe cells consistent with previous reports [12]. Alternatively, the level of substrate does not affect the $A \beta$ rise and other mechanisms are involved.

The results from the current paper suggest that $\gamma$ secretase inhibitors like LY450139 actually increase $A \beta$ levels at low concentrations in vitro without the need of prior inhibition or substrate accumulation occurring. This phenomenon is thus better referred to as an $A \beta$ rise taking place at low concentrations as also suggested by others $[9,12]$.

Having established the mode of action of LY450139 in vitro (although not the detailed molecular mechanism), we next studied how a BACE inhibitor affects the LY450139-evoked A $\beta$ rise and LY450139 inhibitory potency in SH-SY5Y APPwt and APPswe cells. The BACE inhibitor prevented the $A \beta$ rise in a concentration-dependent manner in APPwt cells, although the 


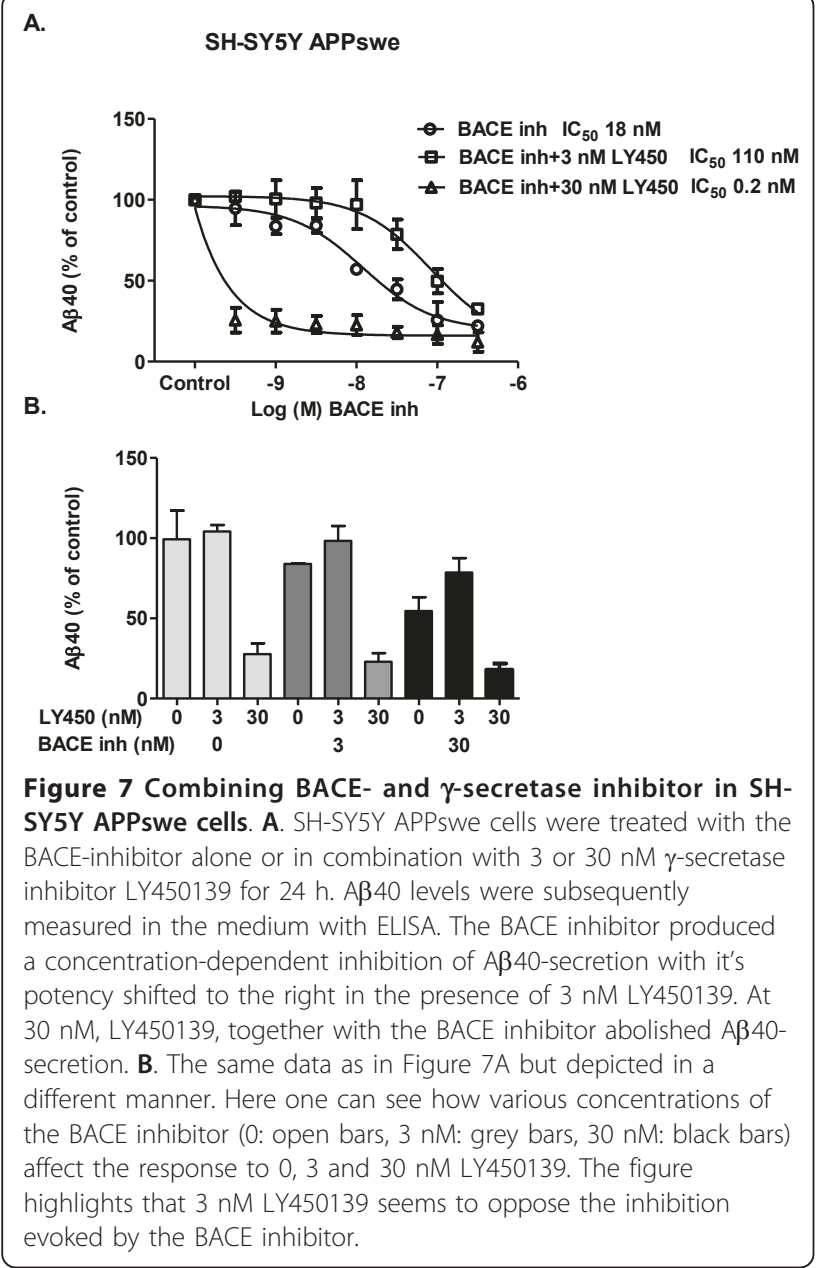

BACE inhibitor potency was shifted to the right (from 7

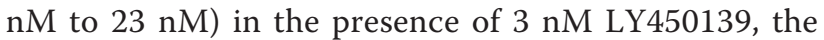
concentration that normally increases $A \beta$ secretion. The concentration-dependent inhibition suggests that ongoing BACE- 1 activity is required for the $A \beta$ rise to occur. This offers further support that the $\gamma$-secretase inhibitor-induced increases in $A \beta$ levels are not due to rebound effects in response to substrate accumulation (i. e. C99 fragment) since this mechanism would not likely be BACE-1 dependent. Combining a BACE inhibitor with $30 \mathrm{nM}$ LY450139 did not have any obvious advantage in APPwt cells, the BACE inhibitor potency being more or less the same as in the presence of BACE inhibitor alone (10 nM vs.7 nM). LY450139 at the concentration of $30 \mathrm{nM}$ does not per se affect secreted $\mathrm{A} \beta$.

Interestingly, despite the lack of an $\mathrm{A} \beta$ rise in $\mathrm{SH}$ SY5Y APPswe cells, $3 \mathrm{nM}$ of LY450139 clearly shifted the BACE inhibitor concentration-response curve to the right (18 $\mathrm{nM}$ vs. $110 \mathrm{nM}$ ). This suggests that also in APPswe cells, a low concentration of LY450139 is trying to raise $A \beta$ levels but not enough to detect under basal conditions. However, it appears to be manifested in the presence of the BACE inhibitor, not by increasing $A \beta$ levels but by counteracting BACE inhibition. Indeed, small signs of an $A \beta$ rise in response to $3 \mathrm{nM}$ LY450139 can be seen in the presence of 3 and $30 \mathrm{nM}$ BACE inhibitor in APPswe cells. It is possible that as $\gamma$-secretase substrate falls in response to BACE inhibition, an A $\beta 40$ rise is triggered in response to low concentrations of LY450139 even in APPswe cells. By contrast, higher concentrations of LY450139 (30 nM), shifted the BACE inhibitor curve to the left, but it is important to keep in mind that this concentration of LY450139 per se has considerable inhibitory effects making conclusions on possible synergy difficult. The current study thus fails to detect any obvious synergies between $\gamma$-secretase and BACE-1 inhibition in SH-SY5Y APPwt- or in APPswetransfected cells. However, closer titration of inhibitors is warranted in future studies, for instance using a higher concentration of LY450139 (e.g. $60 \mathrm{nM}$ ).

\section{Conclusions}

Combined BACE- 1 and $\gamma$-secretase inhibition is complex and the outcome is likely to vary depending on substrate levels. When viewing the results from $\gamma$-secretase perspective, BACE- 1 inhibition can prevent the $A \beta$ rise evoked by $\gamma$-secretase inhibition at low concentrations without showing any obvious potentiation at higher concentrations. By contrast, from a BACE-1 perspective, adding the $\gamma$-secretase inhibitor LY450139 did not potentiate BACE-mediated inhibition but rather shifted the concentration-response curve to the right, most likely due to LY450139 trying to raise A $\beta$ levels at low concentrations. Hence, adding a BACE inhibitor to a $\gamma$ secretase inhibitor like LY450139 could have advantages by preventing the $A \beta$ rise.

\section{Authors' contributions}

AJ carried out the experiments in SH-SY5Y cells, participated in the design of the study and drafted the manuscript. OB was responsible for the synthesis of the inhibitors used in the study. ME designed the plasmids used for transfection of the cells. EL organized the study, participated in the study design and revised the manuscript. All authors read and approved the final manuscript.

\section{Competing interests}

The authors declare that they have no competing interests.

Received: 30 May 2011 Accepted: 21 October 2011

Published: 21 October 2011

\section{References}

1. Thinkakaran $\mathrm{G}, \mathrm{Koo} E \mathrm{EH}$ : Amyloid precursor protein trafficking, processing and function. J Biol Chem 2008, 283:29615-29619.

2. Shankar GM, Li S, Mehta TH, Garcia-Munoz A, Shepardson NE, Smith I, Brett FM, Farrell MA, Rowan MJ, Lemere CA, Regan CM, Walsh DM, Sabatini BL, Selkoe DJ: Amyloid-beta protein dimers isolated directly from Alzheimer's brains impair synaptic plasticity and memory. Nat Med 2008, 14:837-842. 
3. Bateman RJ, Siemers ER, Mawuenyega KG, Wen G, Browning KR, Sigurdson WC, Yarasheski KE, Friedrich SW, Demattos RB, May PC, Paul SM, Holtzman DM: A gamma-secretase inhibitor decreases amyloid-beta production in the central nervous system. Ann Neurol 2009, 66(1):48-54.

4. Wong GT, Manfra D, Poulet FM, Zhang Q, Josien H, Bara T, Engstrom L, Pinzon-Ortiz M, Fine JS, Lee HJ, Zhang L, Higgins GA, Parker EM: Chronic treatment with the gamma-secretase inhibitor LY-411,575 inhibits betaamyloid peptide production and alters lymphopoiesis and intestinal cell differentiation. J Biol Chem 2004, 279:12876-12882.

5. Hyde LA, McHugh NA, Chen J, Zhang Q, Manfra D, Nomeir AA, Josien H, Bara T, Clader JW, Zhang L, Parker EM, Higgins GA: Studies to investigate the in vivo therapeutic window of the gamma-secretase inhibitor $\mathrm{N2}$ [(2S)-2-(3,5-difluorophenyl)-2-hydroxyethanoyl]-N1-[(7S)-5-methyl-6-oxo6,7-dihydro-5H-dibenzo[b, d]azepin-7-yl]-L-alaninamide (LY411,575) in the CRND8 mouse. J Pharmacol Exp Ther 2006, 319:1133-43.

6. Henley DB, May PC, Dean RA, Siemers ER: Development of semagacestat (LY450139), a functional $\gamma$-secretase inhibitor, for the treatment of Alzheimer's disease. Expert Opin Pharmacother 2009, 10:1657-1664.

7. Martone RL, Zhou H, Atchison K, Comery T, Xu JZ, Huang X, Gong X, Jin M, Kreft A, Harrison B, Mayer SC, Aschmies S, Gonzales C, Zaleska MM, Riddell DR, Wagner E, Lu P, Sun SC, Sonnenberg-Reines J, Oganesian A, Adkins K, Leach MW, Clarke DW, Huryn D, Abou-Gharbia M, Magolda R, Bard J, Frick G, Raje S, Forlow SB, Balliet C, Burczynski ME, Reinhart PH, Wan HI, Pangalos MN, Jacobsen JS: Begacestat (GSI-953): a novel, selective thiophene sulfonamide inhibitor of amyloid precursor protein $\gamma$-secretase for the treatment of Alzheimer's disease. $J$ Pharmacol Exp Ther 2009, 331:598-608.

8. Kreft AF, Martone R, Porte A: Recent advances in the identification of $\mathrm{Y}^{-}$ secretase inhibitors to clinically test the $A \beta$ oligomer hypothesis of Alzheimer's Disease. J Med Chem 2009, 52:6169-6188.

9. Lanz TA, Hosley JD, Adams WJ, Merchant KM: Studies of Abeta pharmacodynamics in the brain, cerebrospinal fluid, and plasma in young (plaque-free) Tg2576 mice using the gamma-secretase inhibitor N2-[(2S)-2-(3,5-difluorophenyl)-2-hydroxyethanoyl]-N1-[(7S)-5-methyl-6oxo-6,7-dihydro-5H-dibenzo[b, d]azepin-7-yl]-L-alaninamide (LY-411575). J Pharmacol Exp Ther 2004, 309:49-55.

10. Lanz TA, Karmilowicz MJ, Wood KM, Pozdnyakov N, Du P, Piotrowski MA, Brown TM, Nolan CE, Richter KEG, Finley JE, Fei Q, Ebbinghaus CF, Chen YL, Spracklin DK, Tate B, Geoghegan KF, Lau LF, Auperin DD, Schachter JB: Concentration-dependent modulation of amyloid-beta in vivo and in vitro using the gamma-secretase inhibitor, LY-450139. J Pharmacol Exp Ther 2006, 319(2):924-933.

11. Siemers E, Skinner M, Dean RA, Gonzales C, Satterwhite J, Farlow M, Ness D, May PC: Safety, tolerability, and changes in amyloid beta concentrations after administration of a gamma-secretase inhibitor in volunteers. Clin Neuropharmacol 2005, 28(3):126-32.

12. Burton CR, Meredith JE, Barten DM, Goldstein ME, Krause CM, Kieras CJ, Sisk L, Iben LG, Polson C, Thompson MW, Lin XA, Corsa J, Fiedler T, Pierdomenico M, Cao Y, Roach AH, Cantone JL, Ford MJ, Drexler DM, Olson RE, Yang MG, Bergstrom CP, McElhone KE, Bronson JJ, Macor JE, Blat $Y$, Grafstrom RH, Stern AM, Sieffert DA, Zaczek R, Albright CF, Toyn JH: The amyloid- $\beta$ rise and $\gamma$-secretase inhibitor potency depend on the level of substrate expression. J Biol Chem 2008, 283:22992-23003.

13. Lanz TA, Wood KM, Richter KEG, Nolan CE, Becker SL, Pozdnyakov N, Martin B-A, Du P, Oborski CE, Wood DE, Brown TM, Finley JE, Sokolowski SA, Hicks CD, Coffman KJ, Geoghegan KF, Brodney MA, Liston D, Tate B: Pharmacodynamics and pharmacokinetics of the $\gamma$-secretase inhibitor, PF-3084014. J Pharmacol Exp Ther 2010, 334(1):269-277.

14. Lilly Halts Development of Semagacestat for Alzheimer's Disease Based on Preliminary Results of Phase III Clinical Trials. 2010 [http://www.lilly.com].

15. Meredith $J E$, Thompson $L A$, Toyn $J H$, Marcin L, Barten DM, Marcinkeviciene J, Kopcho L, Kim Y, Lin A, Guss V, Burton C, Iben L, Polson C, Cantone J, Ford M, Drexler D, Fiedler T, Lentz KA, Grace JE Jr, Kolb J, Corsa J, Pierdomenico M, Jones K, Olson RE, Macor JE, Albright CF: P-glycoprotein efflux and other factors limit brain amyloid $\beta$ reduction by $\beta$-site amyloid precursor protein-cleaving enzyme 1 inhibitors in mice. J Pharmacol Exp Ther 2008, 326:502-513.

16. Chang W-P, Koelsch G, Wong S, Downs D, Da H, Weerasena V, Gordon B, Devasamudram T, Bilcer $G$, Ghosh AK, Tang J: In vivo inhibition of $A \beta$ production by memapsin 2 ( $\beta$-secretase) inhibitors. $J$ Neurochem 2004 89:1409-1416.
17. Hussain I, Hawkins J, Harrison D, Hille C, Wayne G, Cutler L, Buck T, Walter D, Demont E, Howes C, Naylor A, Jeffrey P, Gonzalez MI, Dingwall C, Michel A, Redshaw S, Davis JB: Oral administration of a potent and selective non-peptidic BACE- 1 inhibitor decreases $\beta$-cleavage of amyloid precursor protein and amyloid- $\beta$ production in vivo. J Neurochem 2007, 100:802-809.

18. Machauer $\mathrm{R}$, Laumen $\mathrm{K}$, Veenstra $\mathrm{S}$, Rondeau J-M, Tintelnot-Blomley M, Betsschart C, Jaton A-L, Desrayaud S, Staufenbiel M, Rabe S, Paganetti P, Neumann U: Macrocyclic peptidomimetic $\beta$-secretase (BACE-1) inhibitors with activity in vivo. Bioorg Med Chem Lett 2009, 19:1366-1370.

19. Nishitomi K, Sakaguchi G, Horikoshi Y, Gray AJ, Maeda M, Hirata-Fukae C, Becker AG, Hosono M, Sakaguchi I, Minami SS, Nakajima Y, Li H-F, Takeyama C, Kihara T, Ota A, Wong PC, Aisen PS, Kato A, Kinoshita N, Matsuoka Y: BACE1 inhibition reduces endogenous Abeta and alters APP processing in wild-type mice. J Neurochem 2006, 99:1555-1563.

20. Sankaranarayanan S, Holahan MA, Colussi D, Crouthamel M-C Devanarayan V, Ellis J, Espeseth A, Gates AT, Graham SL, Gregro AR, Hazuda D, Hochman JH, Holloway K, Jin L, Kahana J, Lai M-T, Lineberger J, McGaughey G, Moore KP, Nantermet P, Pietrak B, Price EA, Rajapakse H, Stauffer S, Steinbeiser MA, Seabrook G, Selnick HG, Shi X-P, Stanton MG, Swestock J, Tugusheva K, Tyler KX, Vacca JP, Wong J, Wu G, Xu M, Cook JJ, Simon AJ: First demonstration of cerebrospinal fluid and plasma $A \beta$ lowering with oral administration of a $\beta$-site amyloid precursor proteincleaving enzyme 1 inhibitor in nonhuman primates. J Pharmacol Exp Ther 2009, 328:131-140.

21. Audia JE, Diseroad BA, John V, Latimer LH, Nissen JS, Stephenson GA, Thorsett ED, Tung JS: US 2007/0299053.

22. Charrier N, Clarke B, Cutler L, Demont E, Dingwall C, Dunsdon R, East P, Hawkins J, Howes C, Hussain I, Jeffrey P, Maile G, Matico R, Mosley J, Naylor A, O'Brien A, Redsahw S, Rowland P, Soleil V, Smith K, Sweitzer S, Theobald P, Vesey D, Walter DS, Wayne G: Second generation of hydroxyethylamine BACE-1 inhibitors: optimizing potency and oral bioavailability. J Med Chem 2008, 51(11):3313-7.

23. Mullan M, Crawford F, Axelman K, Houlden H, Lilius L, Winblad B, Lannfelt L: A pathogenic mutation for probable Alzheimer's disease in the APP gene at the N-terminus of beta-amyloid. Nat Genet 1992, 1:345-347.

doi:10.1186/1423-0127-18-76

Cite this article as: Jämsä et al:: BACE-1 inhibition prevents the $\gamma$ secretase inhibitor evoked $A \beta$ rise in human neuroblastoma SH-SY5Y cells. Journal of Biomedical Science 2011 18:76.

\section{Submit your next manuscript to BioMed Central and take full advantage of:}

- Convenient online submission

- Thorough peer review

- No space constraints or color figure charges

- Immediate publication on acceptance

- Inclusion in PubMed, CAS, Scopus and Google Scholar

- Research which is freely available for redistribution

Submit your manuscript at www.biomedcentral com/submit
Ciomed Central 